\title{
Why is water pricing ineffective for deficit irrigation schemes? A case study in southern Spain.
}

\author{
Alfonso Expósito ${ }^{1 *}$ and Julio Berbel ${ }^{2}$ \\ ${ }^{1}$ Department of Economic Analysis, University of Seville, 41018 Seville, Spain; \\ aexposito@us.es \\ 2 Department of Agricultural Economics, University of Cordoba, 14014 Cordoba, \\ Spain; berbel@uco.es \\ $* 1$
}

\begin{abstract}
.
This paper explores the impact on water demand of the adoption of deficit and precision irrigation as a farmer's attempt to respond to water scarcity by maximising water productivity. The case study is characterised by the intensive use of deficit irrigation techniques in olive groves, which account for 50 per cent of all irrigated land in southern Spain. These technologies have an important influence on the structure of the water demand. This study reveals that following the adoption of such technologies, water demand does not respond to moderate changes in water price, unless price increases become so great that they reach a threshold price representing a disproportionate and unaffordable social impact. This fact has significant consequences for water policy as water pricing becomes an ineffective instrument for managing water demand in a context characterised by resource scarcity and farmers' adoption of deficit irrigation techniques.
\end{abstract}

Keywords: water pricing; deficit irrigation; water demand; demand elasticity.

\footnotetext{
${ }^{1}$ Acknowledgments: This research was financed by the Secretaría General de Ciencia, Tecnología e Innovación (MINECO AGL2014-53417-R). The authors acknowledge the suggestions and support of our colleagues from WEARE group, L. Mateos and F. Orgaz from IAS-CSIC.
} 


\section{Introduction.}

Water pricing mechanisms are generally seen as one of the most important instruments for water demand management in the context of the overextraction of water. The use of water pricing is frequently proposed as a strategic tool for water policy,such as in the Water Framework Directive (European Commission 2000) and the Blueprint to Safeguard Europe's Water Resources (European Commission 2012). Moreover, water pricing is seen by many environmental organisations as a social issue and even the agricultural subsidies linked to the European Common Agricultural Policy depend on water pricing and the implementation of cost-recovery strategies.

Advocates of water pricing generally put forward three arguments (Perry 2001). First, it serves as a cost recovery instrument for water services. Second, it provides an incentive for the efficient use of scarce water resources, and third, it acts as a source of finance to continue providing essential water services in the future (Kumar and Singh 2001). Furthermore, water pricing is considered a suitable way of reflecting the economic and social value of the resource and of allocating it efficiently to different uses (Johansson 2000).

This paper analyses the effectiveness of water pricing for irrigation water demand management in areas where deficit irrigation is a predominant strategy adopted by farmers in response to water scarcity. This paper attempts to analyse the behaviour of the water demand function and to estimate the subjective threshold price based on the subjective perceptions of a sample of farmers with intensive irrigated olive groves. Threshold estimates are obtained through marginal productive values of water, elicited from farmers' subjective responses in three different irrigation scenarios. The next section briefly reviews the role of water pricing as an effective measure in water demand management under constrained supply. The third section presents our case study of intensive irrigated olive grove farmers in the Guadalquivir River Basin (southern Spain), followed by the presentation of our main results in section four. The fifth section provides an open discussion about the effectiveness of water pricing policies in the context under study. Finally, the paper ends with some concluding remarks.

\section{State of the art.}

The majority of water pricing related literature focuses on analysing farmers' responsiveness to pricing pressures and how price policies prompt the implementation of more efficient water use techniques. Nevertheless, there is a growing body of literature that concludes that irrigation water demand has a very low elasticity and water pricing is not particularly effective at curtailing water demand. As the price of water is only rarely determined by the market, the analysis of water demand for irrigation becomes problematic. Consequently, the value of water needs to be derived by modelling an optimisation problem of farmers' production function (Dinar and Letey 1996; Rosegrant et al. 2001; Jeder et al. 2014). 
Bernardo and Whittlesey (1989) used a mathematical programming model to show that farmers in Washington State substitute water with labour, by switching to a more water efficient mode of operation of their irrigation technology. Ogg and Hollegon (1989), using econometric curve fitting techniques, concluded that higher water costs will result in relatively modest reductions in per-hectare water use in western US. Regarding the analysis of alternative policies to curtail water use, Dinar and Letey (1996) developed an analytical model to compare the effectiveness of water pricing in four regions in California, arriving at the conclusion that water quantity reduction policies were more effective than water price policies. The impact of irrigation techniques also plays a significant role when the effectiveness of price policies is assessed, as shown in Varela-Ortega et al. (1998). They concluded that in highly efficient irrigation systems (i.e. drip) the response to increasing water prices was much lower than for inefficient irrigation schemes (i.e. surface gravity irrigation). The authors stated that, at least in the Spanish regions studied, irrigation technical endowment was a determining factor in explaining low responsiveness to water pricing among farmers under restricted water supply (demand inelasticity). Several other studies have also shown farmers' limited responsiveness to low water prices under existing allocation practices (OECD 1999; Perry 2001; Ray 2002).

Nevertheless, it is still debatable whether or not water pricing is an effective measure in water demand management (De Fraiture and Perry 2007). Several studies claim that irrigation water demand is inelastic below a threshold price, and elastic beyond it. This would mean that considerable price increases would be required to produce a reduction in demand, and such increases may involve important political considerations.

In our case study, as is the case in many parts of the world, farmers do not freely decide on the amount of water they will use to irrigate their crops, as water access is restricted by water rights (or fixed allocations). Under conditions of water scarcity and low water prices, the amount allocated is likely to be below the amount of water that farmers would be willing to take at the prevailing price, thus promoting the use of deficitirrigation techniques. This would encourage the use of irrigation doses that would maximise returns to water, rather than returns to land as proposed by English (1990) and illustrated, among others, by Expósito and Berbel (2016) and Berbel and Mateos (2014).

Figure 1 shows the relation between water price and demand under a fixedallocation system. At low prices, water demand is constrained by fixed supply $\left(\mathrm{W}_{\mathrm{s}}\right)$ and farmers optimise water use by choosing an appropriate crop, level of risk and efficient irrigation techniques, thus showing no response to price. Conversely, water demand becomes elastic to price at a certain threshold price. This is the point where price equals the productive value of an additional unit of water (water price equals marginal product value of irrigation water). 


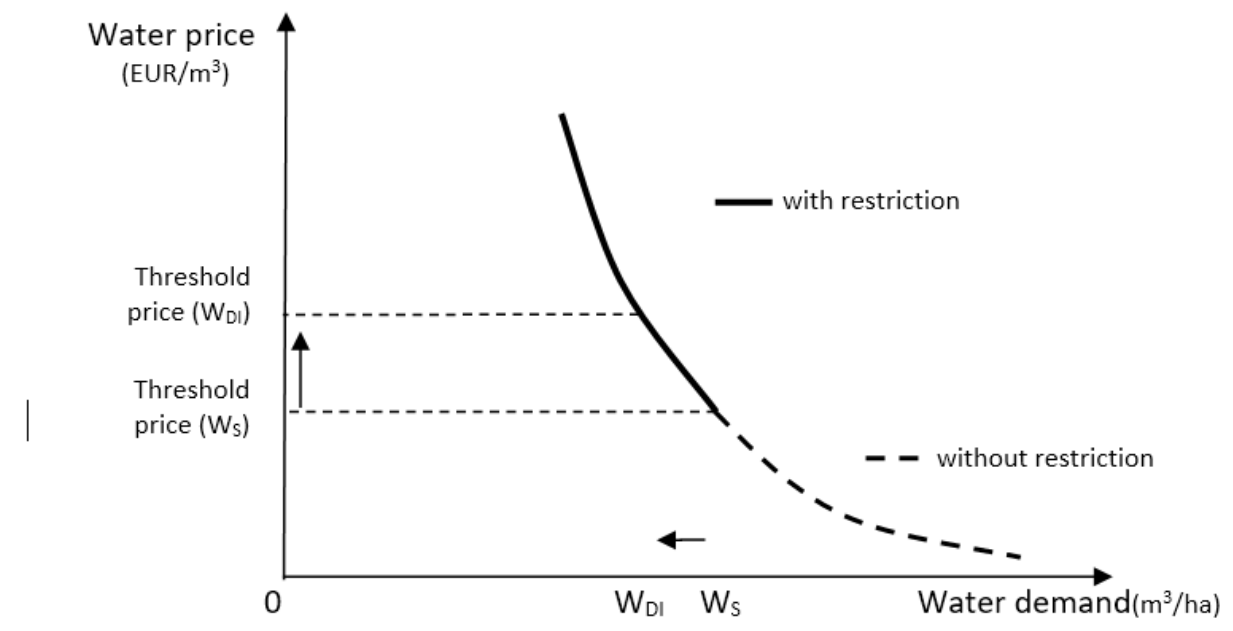

Figure 1. Water demand under restricted supply (Ws) and deficit irrigation (WDI). Adapted from De Fraiture \& Perry (2007)

Alternatively, if the price is set below the threshold and restricted supply is replaced by water pricing measures, farmers will divert more water, until the gap between price and the productive value of water is bridged.

When deficit irrigation (DI) techniques are extensively adopted, farmers' irrigation decisions are shown to be seeking a maximum return to water, as found by Exposito and Berbel (2016).This is because water is considered the fixed factor in this case, instead of the more conventional hypothesis that maximises return to land. Thus, under the predominance of deficit irrigation schemes, the allocated amount of water would fall from $\mathrm{W}_{\mathrm{s}}$ to $W_{\text {DI }}$ (Figure 1), shifting the theoretical threshold price upwards, after which point demand begins to show negative elasticity to price.
As Figure 1 illustrates, water pricing would be effective only if the price is set above a certain threshold, which would be much higher when deficit irrigation techniques are extended in a context of restricted water supply, leading to significant reductions in farmers' profits. In this regard, Berbel and Gómez-Limón (2000) stated that water consumption does not fall until prices reach such a level that farmers' income is negatively affected. If water pricing is selected as a policy measure, farm income would decrease by around $40 \%$ before water demand decreased significantly. Furthermore, Berbel, Pedraza and Giannocaro (2013) explain the trajectory towards closure of the Guadalquivir basin and that one way farmers respond to scarcity is to invest in more efficient high-technology irrigation,along with the widespread implementation of deficit irrigation techniques. The authors argue that significant consequences may occur at the basin or aquifer level when this 
technique is adopted, including the low elasticity of water demand to price variations.

In this regard, several empirical studies show that depending on the initial water price and the size of allocation, this threshold price may be several times the original price. Ray (2002) reported a sixfold price increase for India; and Perry (2001) estimated a tenfold increase for Iran. Furthermore, the concept of a threshold price is relative,depending on several agronomic factors (i.e. type of crop and land) and irrigation technology (i.e. gravity, sprinkler, drip); it is therefore essential to examine the nature and scope of the price threshold in order to assess the potential effectiveness of water pricing in certain agronomic locations (De Fraiture and Perry 2007). This point is especially significant in the case of highly efficient farmers (those who already use highly-efficient irrigation techniques, i.e. drip) and with respect to how their irrigation demand decisions are based on their subjective perceptions and beliefs.

\section{Materials.}

\subsection{Case study.}

The case study selected to analyse farmers' subjective beliefs about the water-yield relationship focuses on irrigated olive groves in Andalucia (southern Spain). The area under study forms part of the Guadalquivir River Basin, which is the longest river in southern Spain, $650 \mathrm{~km}$ in length and with a total combined length including both the river and its tributaries of around $10,700 \mathrm{~km}$. The basin covers an area of $58,000 \mathrm{~km}^{2}$ with a population of 4.1 million (the most populated cities are Seville, Cordoba and Granada). It has a Mediterranean climate with an uneven rainfall distribution $(630 \mathrm{~mm})$ and an average annual temperature of $16.8^{\circ} \mathrm{C}$ (CHG 2010). Annual renewable resources are estimated at $7.110^{9} \mathrm{~m}^{3}$ for surface waters and $2.610^{9} \mathrm{~m}^{3}$ for groundwater. In 2015 (CHG 2016), per capita water consumption in the basin was $875 \mathrm{~m}^{3}$, and agriculture was the top consumer with $88 \%$ of the total. In 2014, the Spanish agricultural area dedicated to irrigated olive trees amounted to 740,511 ha (Berbel and Gutierrez-Martín 2015). Though initially famers simply installed drip irrigation systems into existing traditional groves (100 trees per hectare), new irrigation technologies have allowed farmers to significantly increase tree densities in order to create intensive groves (between 250 and 300 trees per hectare) or super-intensive groves (around 800 trees per hectare).

\subsection{Survey description.}

The focus of the research is intensive olive groves (around 275 trees per hectare) and is based on a survey of irrigated olive growers in the Guadalquivir River Basin regarding yield and irrigation doses per ha, among other data, in the period 2010-2013. The fieldwork was conducted in spring 2014 with information given by 99 farmers of intensive olive groves. This crop is typically irrigated with DI technology and it represents around $50 \%$ of all irrigated land in the Guadalquivir River Basin, or $25 \%$ of total irrigated land in Spain. We have therefore selected this 
crop as a relevant case study for the impact of DI on the effectiveness of water pricing.

The original survey consisted of 99 observations (farmers), and average values in the survey are: a) farm size: 40 ha; b) density: 283 trees/ha; c) water rights: $2,723 \mathrm{~m}^{3} / \mathrm{ha}$; and d) irrigation doses: $1,028 \mathrm{~m}^{3} / \mathrm{ha}$. We observe a discrepancy here, as water use represents $38 \%$ of farmer water rights $(1,028$ / 2,723), indicating the prevalence of the dominant DI strategy among analysed farmers. Descriptive statistics of our survey (crop area, density, age of olive groves and assigned irrigation rights) are summarised in Table 1, together with information regarding average production (olive kilograms) and irrigation dose $\left(\mathrm{m}^{3}\right)$ applied over the period under analysis. Although the variability within the sample seems high, the table shows that the observed farmers tend to apply an irrigation dose far smaller than that permitted according to their assigned water rights, displaying on average a preference for a scenario characterised by DI.
An individual subjective water demand function has been elicited on an individual subjective water-yield curve in the 'normal' agronomic range (maximum yield should be within the normal range for the crop and region), as defined in Expósito and Berbel (2016). The answers given by farmers regarding their expectations as to water consumption $\left(\mathrm{m}^{3} / \mathrm{ha}\right)$ and yield $(\mathrm{k} / \mathrm{ha})$ in three possible irrigation scenarios (extreme DI, usual DI and full irrigation), make possible to estimate a quadratic production function $Y(w)=$ $a_{1}+b_{1} \cdot W+c_{1} \cdot W^{2}$, where $Y$ represents yield and $W$ the applied water dose. Based upon this subjective production function, the farmer's water demand isequal to the marginal product value of water (MPV) defined by the following equation:

$$
M P V=P_{y}^{\prime} \cdot d Y / d W=P_{y}^{\prime} \cdot\left(b_{1}+2 \cdot c_{1} W\right)
$$

In the above function, $\mathrm{P}_{\mathrm{y}}^{\prime}$ is equal to the 'net farm gate price' (i.e. price of olives minus harvesting cost) and parameters $b_{1}$ and $c_{1}$ depend on each farmer and each subjective production function (subject to $b_{1}>0 ; c_{1}<0$ ). A subjective water demand function has then been elicited for each individual farmer. As the demand function is a straight line, it

Table 1. Basic descriptive parameters.

\begin{tabular}{lcccccc}
\cline { 2 - 6 } & Area (ha) & $\begin{array}{c}\text { Density } \\
\text { (trees/ha) }\end{array}$ & $\begin{array}{c}\text { Age } \\
\text { (years })\end{array}$ & $\begin{array}{c}\text { Yield } \\
(\mathrm{k} / \mathrm{ha})\end{array}$ & $\begin{array}{c}\text { Irrigation } \\
\text { rights }\left(\mathrm{m}^{3} / \mathrm{ha}\right)\end{array}$ & $\begin{array}{c}\text { Irrigation } \\
\text { dose } \\
\left(\mathrm{m}^{3} / \mathrm{ha}\right)\end{array}$ \\
\hline Average & 40 & 283 & 15 & 6382 & 2723 & 1028 \\
\hline StDev & 64 & 80 & 6 & 2344 & 1846 & 388 \\
\hline Min & 1 & 208 & 4 & 333 & 200 & 200 \\
\hline Max & 400 & 571 & 30 & 13833 & 7000 & 2500 \\
\hline
\end{tabular}


can be represented by two points: 1) the irrigation dose where maximum yield is achieved and marginal product value ofwater tends to be zero; 2) the marginal product value of water when irrigation dose tends to be zero.

An example of a valid response from farmer number \#61 is shown in Figure 1. In this case, the maximum yield is reached with an irrigation dose of 3,685 $\mathrm{m}^{3} / \mathrm{ha}$ (where the marginal product value of water is zero) and the maximum marginal product value of water is $2.74 \mathrm{EUR} / \mathrm{m}^{3}$ (where no irrigation is applied). From these two values, a subjective water demand function can be estimated.

Following English (1990), the irrigation dose that maximises return to water in the case of Farmer $\# 61$ is $1,783 \mathrm{~m}^{3} / \mathrm{ha}$, close to the usual irrigation dose applied by this farmer, which is $1,500 \mathrm{~m}^{3} / \mathrm{ha}$ with a water cost of $0.05 \mathrm{EUR} / \mathrm{m}^{3}$ in the period 2010-2013. As described by Expósito and Berbel (2016), this farmer's behaviour is based on the usual application of deficit irrigation techniques that maximises return to water as the limited resource, and runs contrary to common microeconomic theory based on the maximisation of returns to land as the limiting productive factor. Based on this farmer's usual irrigation dose of 1,500 $\mathrm{m}^{3} / \mathrm{ha}$, the estimated marginal productivity of water is $1.63 \mathrm{EUR} / \mathrm{m}^{3}$, meaning that this would be the threshold price at which this farmer's water demand function becomes elastic with respect to price. As seen in the previous section, price movements below this threshold would not cause any variation in water demand, as it presents inelasticity in this section of the function. Furthermore, this water allocation is far below the average restricted water supply in our sample (average irrigation rights of 2,723 $\mathrm{m}^{3} / \mathrm{ha}$ ) and the average irrigation dose that maximises yield $\left(3,685 \mathrm{~m}^{3} / \mathrm{ha}\right)$. Any price increase above the threshold would mean a reduction in the economic rent associated with water, as shown in Figure 2 by the area above the $\mathrm{CP}$ line and below the demand function. Any increase in the price of water in the

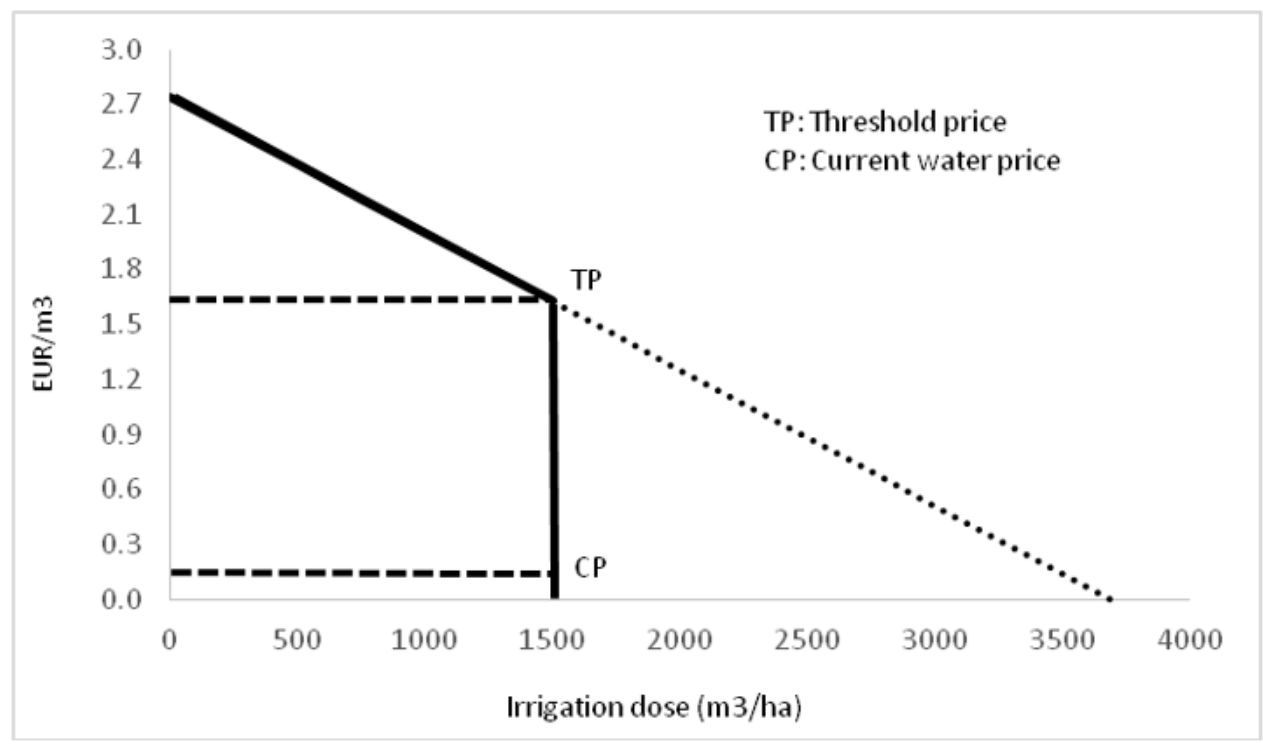

Figure 2. Elicited marginal value of water for Farmer \#61. 
range 0.05-1.63 EUR $/ \mathrm{m}^{3}$ would mean a reduction in the resource rent associated with water and thus, a reduction of Farmer \#61's surplus. Only price increases above $1.63 \mathrm{EUR} / \mathrm{m}^{3}$ would lead to a reduction in the applied irrigation dose to below $1,500 \mathrm{~m}^{3} / \mathrm{ha}$.

\section{Results.}

From our initial sample of 99 farmers, 21 were discarded as they provide information about only two levels of our elicited water-yield relationship,implying that it was not possible to estimate an elicited production function inthese cases. Additionally, 30 observations, despite providing information on the three irrigation levels, presented estimation errors (i.e. increasing returns to scale) and were therefore notconsidered valid responses. Consequently, our sample was reduced to 48 valid behavioural observations.

Based on the valid observations, Table 2 shows descriptive statistics of individual elicited threshold price of water given by the estimated marginal product value of water at the usual irrigation dose applied by each farmer, together with information regarding the current water cost. While the variability of the observations seems high, they all display a similar 'rational' response regarding irrigation decisions, the water production function exhibits decreasing returns to scale, and marginal values are similar to those observed and in line with agronomic experience (MesaJurado et al. 2010). The average estimated marginal product value associated with the average applied water dose in our sample shows that the threshold price would be around 1.2 $\mathrm{EUR} / \mathrm{m}^{3}$, which is 10 times the current average water cost paid by oursample offarmers $\left(0.11 \mathrm{EUR} / \mathrm{m}^{3}\right)$

Table 2. Water cost and elicited threshold price.

\begin{tabular}{|l|c|c|c|}
\cline { 2 - 4 } \multicolumn{1}{c|}{} & $\begin{array}{c}\text { Water cost } \\
\left.\text { (EUR } / \mathrm{m}^{3}\right)\end{array}$ & $\begin{array}{c}\text { Applied } \\
\text { Water dose } \\
\left(\mathrm{m}^{3} / \mathrm{Ha}\right)\end{array}$ & $\begin{array}{c}\text { Threshold Price } \\
\left(\mathrm{EUR} / \mathrm{m}^{3}\right)\end{array}$ \\
\hline Maximum & 0.30 & 2,500 & 4.68 \\
\hline Minimum & 0.05 & 600 & 0.20 \\
\hline Median & 0.08 & 1,042 & 1.03 \\
\hline Average & 0.11 & 1,103 & 1.22 \\
\hline St. Dev. & 0.09 & 350 & 0.88 \\
\hline
\end{tabular}
Source: Own elaboration.

As mentioned above, the threshold price is influenced by the technology choice adopted by the farmer and the existing water management practices in the river basin. These two factors usually lead to an evolution of the economic value of water characterized by an increase of the marginal product value of water. Further, when DI techniques are widely adopted, an increase of the threshold price also occurs. Consequently, the marginal product value of water and the threshold price determine the structure of water demand and evolve independently from water cost, which is related to supply evolution and water policy measures. Thus, in the irrigated olive case study, water cost would not be expected to play a key role in determining our farmers' subjective water demand unless water price levels increase disproportionally and above the threshold price. Figure 3 shows water dose-water cost combinations wherein two groups can be seen. On the one hand, farmers that apply surface 
irrigation with a cost of around 0.05 $\mathrm{EUR} / \mathrm{m}^{3}$, defined at a basin level by an administrative tariff plus the farmer distribution cost. In our farmers' sample, these cases show a very homogeneous cost. The other group is circumscribed to farmers using groundwater and other surface sources, who face more heterogeneous and higher water costs. reaches a threshold that is significantly higher than current water price level.

The case of our sample's median farmer is illustrated in Figure 4. In this case, the threshold price of water is estimated at $1.03 \mathrm{EUR} / \mathrm{m}^{3}$, which is far higher than the median cost of water $(0.08$ $\mathrm{EUR} / \mathrm{m}^{3}$ ) and our sample's maximum value $\left(0.30 \mathrm{EUR} / \mathrm{m}^{3}\right)$. The grey shaded area represents the estimated economic

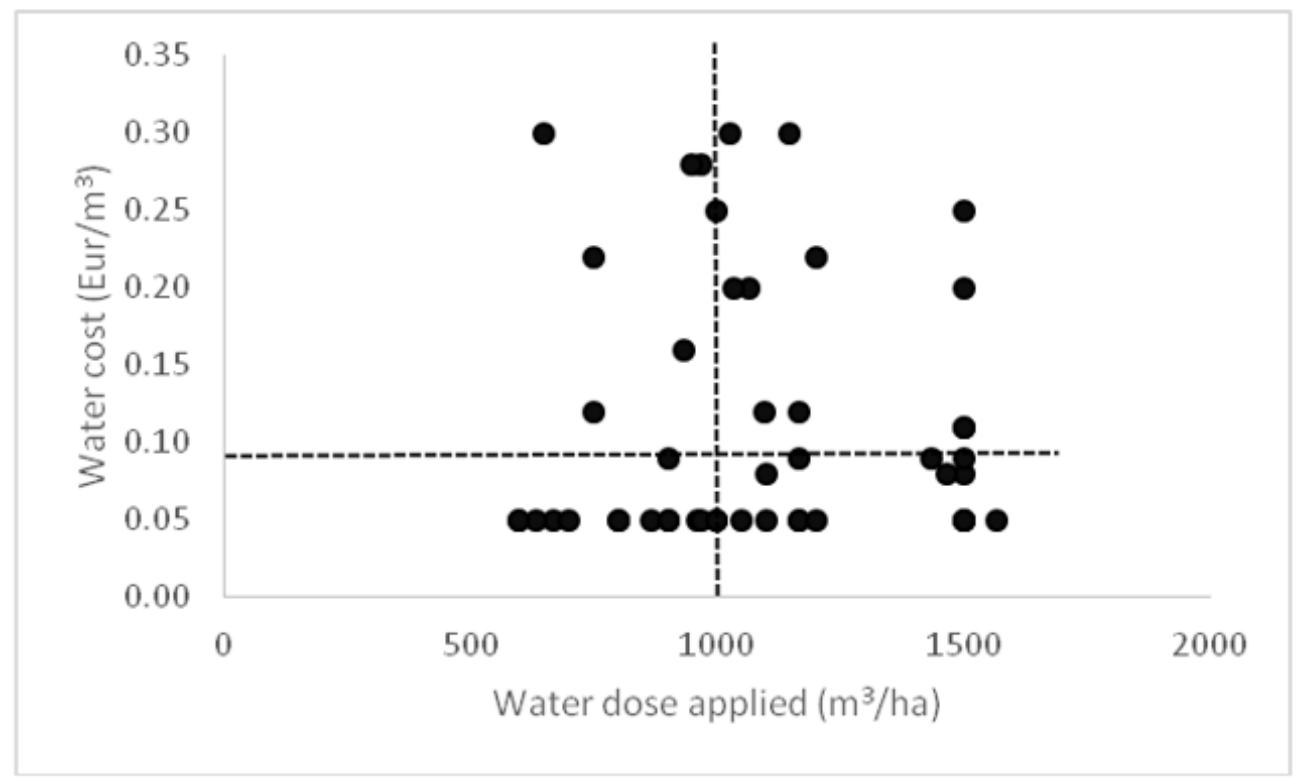

Figure 3. Water cost vs applied water dose.

Figure 3 also illustrates our sample's median water dose $\left(1,042 \mathrm{~m}^{3} / \mathrm{ha}\right)$ and it can be seen that water dose-water cost combinations are randomly distributed around this line. In order to test the response of water demand to water cost among our sample of farmers, a Pearson's correlation coefficient between water cost and applied irrigation dose in our farmers' sample has been calculated showing that no correlation exists between these two variables (with $\mathrm{p}=-0.0089$ ), therefore confirming the existence of a vertical demand curve until the water price rent associated with the resource and thus, with the farmer's surplus obtained by the application of the DI technique. In this case, and taking the maximum observed cost of water in our sample $\left(0.30 \mathrm{EUR} / \mathrm{m}^{3}\right)$, the estimated economic rent would be equivalent to 1,099 EUR/ha.

Figure 4 illustrates the water rent estimation, according to the definitions by Young and Loomis (2014). The figure shows marginal product value of water that is very close to those of Mesa-Jurado et al. (2010) who base 


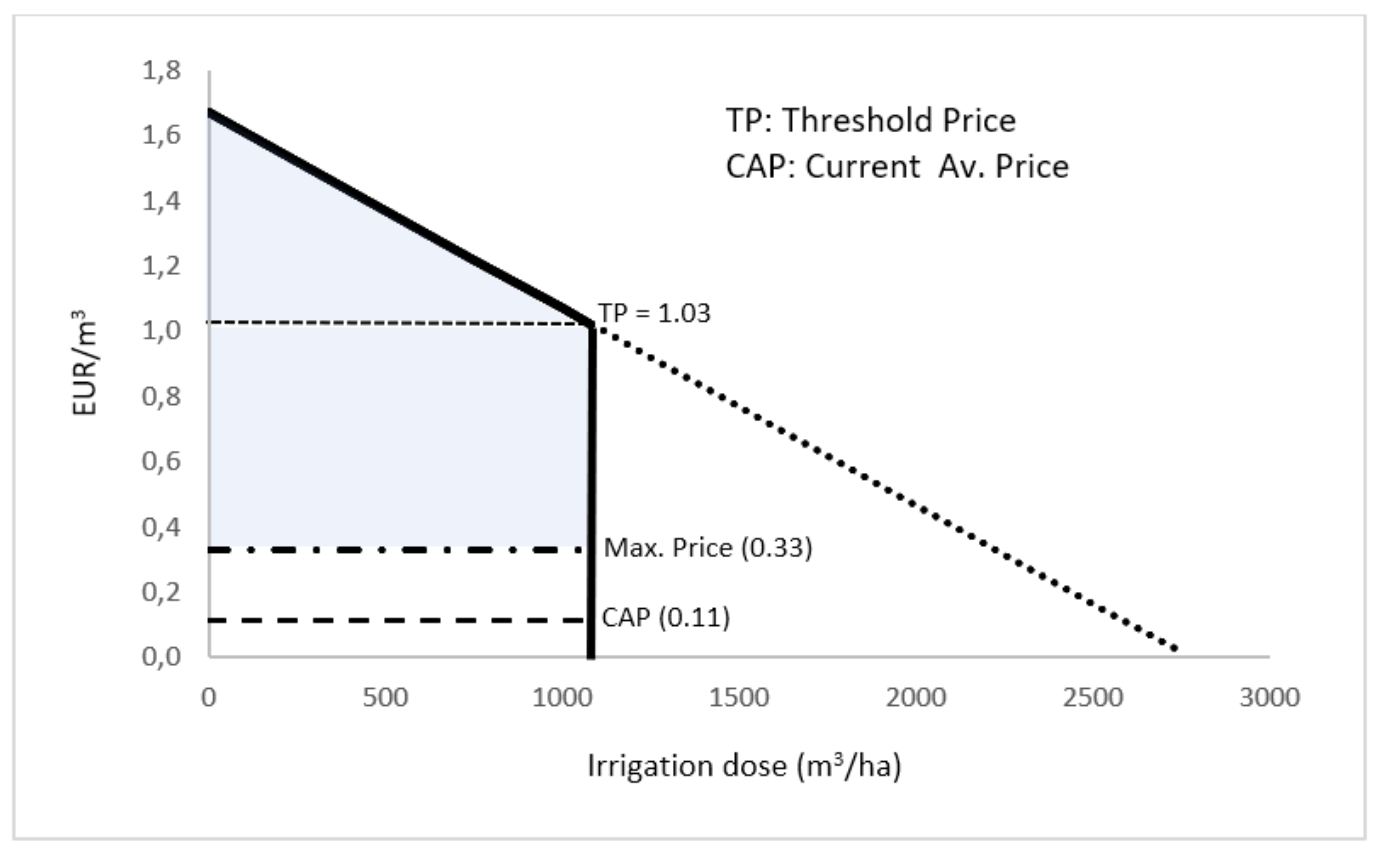

Figure 4. Median farmer's elicited water demand.

their analysis for irrigated olives in an agronomic empirically derived wateryield response function, which is an alternative approach to our research that is based on subjective farmer beliefs. The similarity between our results based on farmer expectations and those based upon derivation of agronomic production function may be explained because farmers make their water volume decision considering scientific (agronomic field research) and administrative (the Basin Agency and Regional Government) information available and consequently, their personal experience may be reinforced by the knowledge from public domain explaining the convergence of farmer subjective expectations and public available agronomic functions.

\section{Discussion.}

The relevance of our analysis is based on the fact that the Guadalquivir basin is the most important river basin in
Spain in terms of Gross Added Value (GVA) by irrigation and that around $50 \%$ of the irrigated land in this basin consists of olive groves. The findings of our survey confirm that our farmers' average water cost of $0.11 \mathrm{EUR} / \mathrm{m}^{3}$ is equal to the official figure for the Andalucia region (CAP 2011), and lies in the lower segment of the survey's range (0.05-0.30).

Furthermore, as our sample is composed of farmers of intensive olive groves, which use highly efficient irrigation schemes (i.e. drip), the inelasticity of water demand should be greater than with "more traditional" irrigation schemes (Varela-Ortega et al. 1998). So, the high technical capacity in our sample of farmers would have a major effect on their response to water pricing, pushing the threshold up far above the average current cost of $0.11 \mathrm{EUR} / \mathrm{m}^{3}$.

All farmers in our survey have adopted a DI strategy, which has become the predominant technique in the Guadalquivir River Basin (CHG 2016). 
One of the consequences of this behaviour is that water demand becomes inelastic with respect to price, as the DI dose implies a vertical demand function up to a threshold given by the marginal product value of water at this DI level. This demand function behaves as described by de Fraiture and Perry (2007), namely an inelastic function up to a threshold price due to water scarcity conditions. We agree with these authors as to the consequences of adopting a DI strategy, but the innovative contribution made by our research is that we show this behaviour to be a voluntary strategy aimed at maximising water productivity, according to English's paradigm (English 1990). The question then becomes, how much can the farmer irrigate with a restricted volume of water? The response derived from our case study show that the applied irrigation dose is not determined by an external (administrative or natural) constraint as De Fraiture and Perry (2007) suggest, but by a deliberated and voluntary decision of farmers to maximise water productivity and profits through the adoption of a DI strategy.

Current water policy in the European Union is strongly rooted in the use of water pricing as a critical instrument. In fact, this is the aim of the Art 9. In the Water Framework Directive (European Commission, 2000) that forces the Member State to estimate the cost recovery ratio of water services and the application of full cost recovery and the use of water pricing to incentive water saving by farmers. The strategic analysis made by 'Blueprint for water Communication'

(European
Commission, 2012) enforces this instrument and the revision of the made by the Member States for River Basin Program of Measures (European Commission, 2015) recently reclaims an increase in water price to control water use.

The term water price is misleading as the water has not a price itself and markets are not fully developed in Spain. The terms should be changed to water tariff when the water comes from a public supply source or water cost when it is self-supply.

The policy makers in Europe and elsewhere understands water pricing as an incentive related to how water users pay for their use, and whether the right price signals are transmitted, i.e. how water is being paid for, and how the water price affects water user behavior, as defined in EEA Technical Report (European Environment Agency, 2013).

In this context, our research highlights the fact that given the widespread of DI techniques and its high efficiency in the use of water among intensive olive groves farmers in the Guadalquivir basin (as a result of an intense modernization process (Aldaya et al., 2012) and as a conscious strategy of farmers to maximize water productivity (see Geert and Raes, 2009; Exposito and Berbel, 2016)), water pricing seems to be ineffective unless tariffs reach a disproportionate threshold level. In this context, administrative authorities should take this fact into account in order to develop more effective water management policies, such as a reform of allocation system of water rights, the promotion of water markets (created in Spain, but not sufficiently developed), 
or the conditioning of CAP benefits to the fulfillment of specific requirements of the WFD regarding water uses and savings.

Nevertheless, some authors take the opposite view to the European policy makers arguing that the causal relationship between low prices and waste seems weak, especially in those countries or RBDs with inefficient conveyance infrastructures and/or inefficient tariff structures (i.e. flat tariffs rather than volumetric tariffs). In general, it has been observed that the elasticity of demand for irrigation water at current rates is low or negligible (de Fraiture and Perry, 2007). Nevertheless, we are aware that price ranges are not the only determinant of demand elasticity, as other factor come into play, such as efficiency gains due to modernization of irrigation techniques (i.e. drip irrigation in our sample of intensive olive groves). When water efficiency is already high, there is no possibility of reducing water use, so higher prices will only affect farmers' incomes (Berbel et al., 2007).

In our opinion, two related but separate issues concern water pricing and water policy. On the one hand, advocates of water pricing support the hypothesis that water pricing is the solution to over-extraction and excessive water use. On the other hand, the European Water Framework Directive (Art. 5) contains a compulsory requirement that the price of water should be set according to the goal of achieving full cost recovery, including environmental and resource costs (E\&RC). The two arguments are compatible with each other, and some scholars and environmental activists believe that water price is heavily subsidised so full cost recovery should be enough to solve the problem of overexploitation.

Regarding full cost recovery, the evidence in the Guadalquivir River Basin shows that financial cost recovery is approximately $86 \%$ (all uses and sources considered) according to the Basin Hydrological Plan (CHG 2013). Along these lines, Krinner (2014) estimates an overall cost recovery rate for Spain of $72 \%$. Recently, BorregoMarín, Gutiérrez-Martín and Berbel (2015) estimated a financial cost recovery ratio of $73 \%$ for surface water in the Guadalquivir Basin, attributing the difference to subsidies for 'modernisation of the water network'. Although there is a general consensus on achieving a cost recovery rate of $100 \%$, eliminating subsidies for agricultural irrigation, the average increase in water cost would be around $0.04 \mathrm{EUR} / \mathrm{m}^{3}$, from 0.11 to 0.15 $\mathrm{EUR} / \mathrm{m}^{3}$ in the Guadalquivir Basin, what would not lead to a significant reduction in water demand as shown in our case study.

Some scholars and stakeholder believe that the water price should be raised above full financial cost recovery, including certain eco-taxes that help to internalise E\&RC. Nevertheless, the value of this type of costs is difficult to estimate, and there is no commonlyaccepted methodology (Martin-Ortega et al. 2011; Gawel 2014). In any case, as we have shown, the required increase in price in order to impact water demand would be disproportionate (multiplying the current price by almost 10) and it would entail a substantial reduction in farmers' income, as they 
would be required to transfer part of their economic surplus to the Administration via water tariffs.

\section{Concluding remarks.}

This paper analyses the impact that the generalized adoption of deficit irrigation strategies has on the water governance and water pricing effectiveness. This work shows that water demand becomes more inelastic after adoption of this technology and the consumption does not respond to small changes in water price because the water demand is vertical until water cost reaches a threshold price. We have worked upon a sample of irrigated olive farmers and found that the threshold price upon which farmers would demand less irrigation water is far above current water prices. Consequently, the marginal product value of water and the threshold price determine the structure of water demand and evolve independently from water cost. This result may be generalized beyond olive irrigated to all crops that use this technique (such as almond trees and other resintant crops to water scarcity).

As main conclusion, water pricing is an ineffective instrument in areas characterized by water scarcity and supply restrictions (i.e. in overexploited aquifers and basins), as it is the case of the Guadalquivir river basin in southern Spain (and in many other parts of the world with similar climatic and hydrological conditions). In our case (as in other empirical studies such as Berbel and Gómez-Limón (2000), Perry (2001) and Ray (2002), the elicited threshold price represents a disproportionate and unaffordable cost of the resource from a social point of view. This finding implies significant consequences for water management in river basins, such as the Guadalquivir basin, as water pricing becomes an ineffective instrument for managing water demand in a context characterised by resource scarcity and a generalized adoption of deficit irrigation techniques by farmers. The paradox is that after the adoption of these technologies, water demand does not respond to marginal and small changes in water price. As a result, water pricing is an ineffective instrument in areas where water is more indispensable, i.e. in over-exploited aquifers and basins.

Our research is based on a case study of irrigated olive groves in southern Spain, and although it describes a specific case and the analyzed sample of interviewed farmers may be small, this crop represents 50 per cent of irrigated land in southern Spain, which is the most important agricultural production area by value in the country, and it is of paramount importance as Spain devotes more than 500,000 hectares to low-dose irrigated olive groves. Nevertheless, our aim is to expand this analysis to a wider sample of farmers and to include global basin analysis, as well as other crops and locations considering both the dynamic nature of basin evolution and the complexities of multiple crop interactions. Moreover, we are aware that the use of water over sustainable limits is frequent in closed basins and aquifers, and that the farmer's more usual response to decreasing water resources is to invest in water saving technologies, what includes deficit irrigation techniques to adapt to this situation. Nevertheless, this behavior 
may further deteriorate water masses, leaving measures of better governance to control water abstractions and to guarantee sustainable uses of water as the only long term solution in water scarce areas of the world.

\section{References.}

Aldaya, M., Cabrera, E., Custodio, E., De Stefano, L., Garrido, A., López-Gunn, E., Llamas, M. R., Villarroya, F., Willaarts, B. (2012) El Agua en España: Bases para un pacto de futuro. Madrid: Fundación Botín.

Berbel, J., Calatrava, J., Garrido, A. (2007) Water pricing and irrigation: a review of the European experience. In F. Molle and J. Berkoff (Eds.), Irrigation Water Pricing. CAB International.

Berbel J, Gómez-Limón JA (2000) The impact of water-pricing policy in Spain: An analysis of three irrigated areas. Agr Water Manage 43(2): 219-238. doi: 10.1016/S0378-3774(99)00056-6

Berbel J, Gutiérrez-Marín C (2015) Farmer's subjective elicited water response function for intensive olives and compromise programming method for irrigation supply decision. Econ Agrar Recur Nat 15: 51-68. doi: 10.7201/earn.2015.02.03

Berbel J, Mateos L (2014) Does investment in irrigation technology necessarily generate rebound effects? A simulation analysis based on an agro-economic model. Agric Syst 128:25-34. doi:10.1016/j.agsy.2014.04.002

Berbel J, Pedraza V, Giannoccaro G (2013) The trajectory towards basin closure of a European river: Guadalquivir. International Journal of River Basin Management 11(1): 111-119. doi: 10.1080/15715124.2013.768625

Bernardo D, Whittlesey N (1989) Factor Demand in irrigated agriculture under conditions of restricted water supplies. Economic Research Technical Bulletin 1765, US Dept. of Agriculture.

Borrego-Marín MM, Gutiérrez-Martín D, Berbel J (2015) Estimation of cost recovery ratio for water services based on the System of Environmental-Economic Accounting for Water. Water Resour Manag 30(2): 767-783. doi:10.1007/s11269-015-1189-2

CAP (2011) Agenda del Regadio Andaluz Horizonte 2015. Consejería de Agricultura y Pesca, Junta de Andalucía. http://www.juntadeandalucia.es/export/dru paljda/

AGENDA_DEL_REGADIO_CONSEJO_ DE_GOBIERNO_x7-4-11x.pdf. Accessed 1 July 2016.

CHG (2010) Propuesta de Proyecto de Plan Hidrológico de la Demarcación Hidrográfica del Guadalquivir.Confederación Hidrográfica del Guadalquivir. MAGRAMA: Madrid, Spain.

CHG (2013) Plan Hidrológico de la Demarcación Hidrográfica del Guadalquivir. Real Decreto 355/2013. Confederación Hidrográfica del Guadalquivir. MAGRAMA: Madrid, Spain.

CHG (2016) Plan Hidrológico de la Demarcación del Guadalquivir. Real Decreto 1/2016. Confederación Hidrográfica del Guadalquivir. MAGRAMA: Madrid, Spain.

De Fraiture C, Perry CJ (2007) Why Is Agricultural Water Demand Irresponsive at Low Price Ranges? In Molle F, Berkhoff $\mathbf{J}$ (ed) Irrigation water pricing: the gap between theory and practice. CABI Publishing and International Water Management Institute, Wallingford, UK, and Colombo, pp. 94-107.

Dinar A, Letey J (1996) Modeling Economic Management and Policy Issues of Water in Irrigated Agricultre. Westport: USA: Praeger Publishers.

English M (1990) Deficit irrigation. I: Analytical framework. J Irrig Drain EASCE 116(3): 399-412.

European Commission (2000) Water Framework Directive. Directive 2000/60/EC of the European Parliament and of the Council of 23 October 2000 
establishing a framework for Community action in the field of water policy. Official Journal L 327, 22/12/200, P.0001-0073. http://eur-lex.europa.eu/legalcontent/EN/TXT/?uri=celex: 32000L0060. Accessed 5 May 2016.

European Commission (2012) Communication from the Commission (COM(2012)673): A Blueprint to Safeguard Europe's Water Resources. European Commision: Brussels.

http://ec.europa.eu/environment/water/bluep rint/index_en.htm. Accessed 5 May 2016.

European Commission (2015) Report on The Implementation Of The Water Framework Directive River Basin Management Plans Member State: Spain. Commission Staff Working Document. Swd (2015) 56 Final. Brussels: European Commission.

European Environment Agency (2013) Assessment of cost recovery through water pricing: Luxembourg: Publications Office of the European Union, Technical report No 16/2013.

Expósito A, Berbel J (2016) Microeconomics of Deficit Irrigation and Subjective Water Response Function for Intensive Olive Groves. Water 8(6): 254. doi:10.3390/w8060254

Gawel E (2014) Article 9 Water Framework Directive: Do we really need to calculate environmental and resource costs?. Journal for European Environmental and Planning Law 11(3): 249-271. doi:10.1163/18760104-01103004

Geerts, S, Raes, D (2009) Deficit Irrigation as an on-farm strategy to maximize crop water productivity in dry areas, Agricultural Water Management, 96: 1275-1284.

Jeder H, Sghaier M, Louhichi K, Reidsma P (2014) Bio-economic modelling to assess the impact of water pricing policies at the farm level in the Oum Zessar watershed, southern Tunisia. Agricultural Economics Review 15(2): 29-47.

Johansson RC (2000) Pricing irrigation water: a literature survey. World Bank. Policy
Research Working Paper. Report N. WPS2449. Washington, USA

Krinner W (2014) Financial analysis of the Spanish water sector. Water Resour Manag28(9): 2471-2490. doi:10.1007/s11269-014-0615-1

Kumar MD, Singh OP (2001) Market instruments for demand management in the face of scarcity and overuse of water in Gujarat, Western India. Water Policy 3: 387-403.

Martin-Ortega J, Giannoccaro G, Berbel J (2011) Environmental and resource costs under water scarcity conditions: an estimation in the context of the European Water Framework Directive. Water Resour Manag 25(6): 1615-1633. doi:10.1007/s11269-010-9764-z

Mesa-Jurado MA, Berbel J, Orgaz F (2010) Estimating marginal value of water for irrigated olive grove with the production function method. Span J Agric Res 8(S2), 197-206. doi:10.5424/sjar/201008S2-1362

OECD (1999) Agricultural water pricing in OECD countries. OECD Working Papers 7(33). Paris, France: OECD.

Ogg CW, Gollehon NR (1989) Western irrigation response to pumping costs: a water demand analysis using climatic regions.Water Resour Res 25:767.

Perry CJ (2001) Charging for irrigation water: the issues and options, with a case study from Iran. Research Report 24. Colombo, Sri Lanka: International Water Management Institute.

Ray I (2002) Get the prices right: A model of water prices and irrigation efficiency in Maharashtra, India. In Molle F, Berkoff J (ed) Irrigation Water Pricing. The gap between theory and practice. CABI Publishing and International Water Management Institute, Wallingford UK and Colombo, pp 108-125.

Rosegrant M, Ringler C, McKinney DC, Cai X, Keller A, Donoso G (2001) Integrated economic-hydrologic water modeling at the basin sacle: The Maipo River Basin, 
Chile. International Food Policy Research Institute. Washington D.C.

Varela-Ortega C, Sumpsi JM, Garrido A, Blanco M, Iglesias E (1998) Water pricing policies, public decision making and farmers' response: Implications for water policy. Agr Econ 19(1-2): 193-202. doi: 10.1016/S0169-5150(98)00048-6

Young RA, Loomis JB (2014). Determining the economic value of water: concepts and methods. Routledge, London, UK. 